\title{
The Evolving Role and Influence and Growing Strength of Social Movements in Latin America and the Caribbean
}

\author{
Ricardo Fuentes-Nieva and Gianandrea Nelli Feroci
}

\begin{abstract}
This chapter argues that we are witnessing new processes of social participation and activism in Latin America, characterised by the absence of defined centres of deliberation and coordination, and by transitory leadership. This activism is part of a wider global wave of social protests that began with the Arab Spring in 2011, with which it shares common features such as the generational factor, the role of social media and networks and the use of information and communication technologies (ICTs), the gap between institutional politics and the citizenry, and the weakening of the convening and mobilisation power of classic social movements. The period 2011-15 was characterised by the emergence of this new kind of social activism in Latin America. This form of activism is growing in a specific regional context of increasing contradictions arising from exclusionary socio-economic development and incomplete human development characterised by radical social inequalities in democracies that still do not attend to the needs of large parts of society. Although these social movements may seem new, they are in fact the expression of underlying tensions present in most societies of the region; points of tension that have long represented the core of social conflict in Latin America: inequality, poverty and the exclusion they both imply. This exclusion is social (a lack of access to basic services, education, health and transport, etc.) and political (a lack of participation in decision-making processes, self-referential political classes and opaque institutional processes, and a lack of political-institutional accountability).
\end{abstract}

This chapter is the result of a research and analysis process the authors undertook over three years, as part of their research work for Oxfam, to observe the

* Responsibility for the opinions expressed in this chapter rests solely with the authors and its publication does not constitute an endorsement by OXFAM of the opinions expressed therein.

(C) FUENTES-NIEVA AND NELLI FEROCI, 2017 | DOI 10.1163/9789004351677_015

This is an open access chapter distributed under the terms of the CC-BY-NC License 
panorama of social movements in Latin America and the Caribbean (LAC). The research is based on a mix of direct experience in the field — gained while organising programmes in the region, a literature review, and interviews with key actors. In order to achieve its goals, Oxfam works with and through local civil society organisations (CSOs); thus, a better understanding of the emerging trends in this sector is important for the organisation's strategic thinking and positioning.

The chapter's analytical framework is the academic research being pursued with regard to the emerging social movements linked to the wider global wave of social protests that began with the Arab Spring in 2011-protests in which social networks and media, ICTs, fluidity, a lack of clear leadership, spontaneity, and disenchantment with regard to party politics and institutions are common features and play a key role (Branco, 2014; Castells, 2014; Cardoso, 2014; Calderón and Szmukler, 2014; Pellizzetti, 2014). The authors define a 'social movement' as 'the process of the (re)constitution of a collective identity, outside the context of institutional politics, through which individual and collective action become meaningful' ('el proceso de (re)constitucion de una identidad colectiva, fuera del ambito de la politica institucional, por el cual se dota de sentido a la accion individual y colectiva') (Revilla Blanco, 1996, p.1, our transl.).

The positive trend of economic growth, development and poverty reduction that characterised LAC in the first decade of the twenty-first century has come to a halt, and this may lead to the stagnation of social development or even, in social terms, to new negative trends. At the same time, the region seems to be entering a period of political crisis, in which the progressive regimes, which strategically exploited the economic bonanza in order to foster social development, are now running out of resources, in terms both of political strategies and economic policies. The same is happening in those countries where conservative regimes have retained power. It would seem that most of the countries in the region are reaching the end of a political and economic cycle. At the same time, it must be acknowledged that the progress, in both economic and development terms, of the last decade has formed a new social landscape in LAC, characterised by a growing, but fragile, middle class (or better-off class), and by a citizenry increasingly conscious of its rights. In this context, new forms of active citizenship and social mobilisation have appeared.

Notwithstanding the positive changes of the first decade of the present century, the latest Latinobarómetro results reveal the lowest support for democracy in LAC since the yearly regional public opinion poll began in 1995 . In 2015, only 37 per cent of Latin Americans said they were satisfied with democracy, with record lows in Mexico (19 per cent) and Brazil (21 per cent) 
(Latinobarómetro, 2015). Even though LAC has been characterised by what is commonly defined as the 'golden decade' and has scored better than any other region of the globe in terms of progress in social development, it is the geographical area with the lowest satisfaction with regard to democracy (compared with Africa, Asia, and Europe). That apparent contradiction may be explained by the continuing high levels of inequality in LAC and by a qualitative differentiation between the economic classification of 'middle class' and how the new middle class self-assesses its progress up the social pyramid, especially from a sociopolitical point of view. In fact, in most cases, the new Latin American middle class-richer, more educated, and politically conscious—is still economically vulnerable, and risks falling back into poverty. And, most importantly, it is still excluded from decision making processes, universal social welfare, fair access to justice, better employment opportunities, and is still waiting for a meritocracy to take shape. This perception of exclusion is often amplified by corruption scandals involving the political and economic elites. What the economic statistics do not say is that an important part of the new middle class is still very 'poor' in sociopolitical terms.

It can be argued that Latin American people are-due to democratisation, reduced poverty, advances in education levels and increased access to information-currently traversing a phase in which they are increasingly aware of the situation of economic and political precariousness in which they find themselves and of the injustices that situation implies. Social disparities are no longer perceived as naturally occurring or teleological, but as unacceptable evidence of injustice and dysfunctional states, and these disparities become sources of unrest and issues worth fighting for in order to achieve societal change (PNUD-PAPEP, 2012). It is not by chance that the period 2011-15, when the first symptoms of the end of the economic cycle and the sociopolitical limitations of the growth model started to be felt, was characterised by a (re)emergence of social activism in the region. The social movements fostering this activism grew in a context of the increasing contradictions that arise from fast economic growth combined with exclusionary economic development and from incomplete human development, characterised by radical social inequalities in democracies that still do not attend to the needs of large parts of their societies. They also share common features such as the generational and social class factor (youths, university students, and the urban better-off class play a key role in most of the mobilisations), the role of social media and the use of ICTs, the gap between institutional politics and the citizenry, and the weakening of classic social movements' convening and mobilisation power.

Another common and challenging feature is that most definitions of social movements seem to be too narrow or obsolete to adequately describe what is 
currently happening in LAC, as in other regions of the globe. In most of the countries of the region it would be more accurate to talk about social eruptions of connected networks, which disappear and reappear rapidly to protest against specific issues. ICTs and social media play a key role in this continuous social work in progress, allowing active citizens to stay permanently interconnected and mobilise when a critical mass is built around a specific call for mobilisation. These 'movements' can have an impressive convening power. However, in most cases, their political and economic impact is still unclear, even if some implications can already be identified in sociocultural terms and with regard to emerging players.

In fact, perhaps the most revolutionary aspect of these new social movements lies in their structures and forms of mobilisation and organisation. In political terms however, it remains to be seen whether the new urban middle class is willing to create enduring alliances with traditionally marginalised groups, given the massive concentration of political power, income and wealth still evident in the region, which affects both sides of such potential alliances. Some experiences seem to confirm that a convergence can be found. That is what happened during the paro agrario in Colombia in 2013 when peasant movements and the urban middle class joined forces, and during the \#YoSoyız 2 mobilisations in Mexico in 2012, and the Guatemalan \#RenunciaYa protests in 2015 when private and public university students protested together, something previously unseen. However, this has not yet led to formal political alliances, and seems more linked to a specific coincidence of interests during the demonstrations rather than to long-term strategies.

The above-together with these movements' organisational characteristics - is linked to the question of why, so far, these movements, despite their enormous convening and mobilisation powers, have not been able to bring about actual political (with the partial exceptions of Guatemala and Chile) and structural change, and whether this is likely to change in the near future. We try to answer to these questions through the analysis of three regional case studies, encompassing apparently similar forms of social unrest during recent years but with different outcomes: Brazil, 2013; Mexico, 2012-14; and Guatemala, 2015.

National Cases: Convergences and Divergences

2.1

Political Contexts and Demands

The movements analysed arose in different political contexts and with different dynamics. While the 2013 demonstrations in Brazil took form during the tenure of the reformist and progressive government of Dilma Rousseff, the 
protests in Guatemala and Mexico spread while the conservative and economically liberal governments of Otto Pérez Molina and Enrique Peña Nieto, respectively, were in power. Thus, there is apparently no direct relationship between the protests of recent years and a specific political regime. The absence of clear identification of the movements with classical political ideologies and party politics seems to point towards dissatisfaction with structural issues, such as inequality and exclusion, rather than towards a reaction against a given political ideology. Let us remember here also that Mexico (conservative governments) and Brazil (a progressive government) are the countries with the lowest satisfaction level in the region with regard to democracy. What the Latinobarómetro $(2013 ; 2015)$ results seem to be telling us is that no political regime has done enough to implement those structural changes that are deeply needed in the region; structural changes that would have also contributed to fostering a more positive perception of democracy.

It is important to stress that dissatisfaction with democracy does not mean that the majority of Latin Americans are opposed to democracy as a form of government. On the contrary, $5^{6}$ per cent of the region's people still believe that democracy is preferable to any other kind of government (Latinobarómetro, 2015). What their dissatisfaction tells us is that most of the people in LAC are not satisfied with the way democracy is being applied in the region. In fact, it can be argued that the mobilisations of recent years are deeply linked to democracy and democratic dynamics. They do not argue against the regime; they demand an enhancement of the way in which the regime is functioning. The new movements are the typical expression of societies with a consolidated democratic culture, where debate, criticism, freedom of speech and communication are deeply rooted, and this leads to protests that are typically entrenched in the democratic rules of the game. These protests and their demands for more democracy are paradoxically a symptom of mature democracies. The new social movements in LAC share many commonalities with the new movements in countries considered to be more robust democracies. These movements are found across all democratic systems and are indicators of these systems' dynamism and vitality; and that is a positive trend for the region as a whole.

The disenchantment with democracy can also be explained by the growing disconnect between party politics and the people. In each of the three cases analysed, institutional politics and political parties, both left- and right-wing, were taken by surprise by the size and power of the new movements. They were unable to measure the level of dissatisfaction of the citizenry. This shows how traditional political structures are not effectively linked to the citizenry, and thus were unable to identify in advance the causes of social dissatisfaction. This disconnect can also be considered evidence of the huge level of impunity 
with which political parties and politicians are accustomed to operating in the region without even taking into account the possibility of public indignation, at least until today. Because of this disconnect from society, mainstream politics could not foresee the protest movement coming, nor could it address the roots of dissatisfaction by adapting strategic political actions.

These movements were also a rejection of traditional institutional political players. And it can be argued that they are the result of the increasing distancing of political parties, and unions, from the social reality they should represent. Notwithstanding these shared features however, the movements' relationships with institutional actors change depending on each country's reality. While in Brazil, together with other cases not analysed here such as Chile, there was some sort of approach between the movements and some formal political forces, in Mexico and Guatemala the rejection was sharp.

Only once massive social unrest erupted did those political forces - that are supposedly sympathetic to social demands - try, opportunistically, to establish ties with the new social movements. However, with the partial exception of Brazil — where the Socialism and Liberty Party (Partido Socialismo e Liberdade), the Unified Socialist Workers' Party (Partido Socialista dos Trabalhadores Unificado) and the Revolutionary Communist Party (Partido Comunista Revolucionário) joined and participated actively in the mobilisations - these moves were unsuccessful and were openly rejected by the movements. In Mexico, attempts by the Democratic Revolutionary Party (Partido Revolucionario Democrático) and the National Regeneration Movement (Movimiento Regeneración Nacional) to exploit the protests and ally with the movements failed. While, in Guatemala, political parties were openly invited not to participate in the protests, which were against the entire political system that they themselves represented, and those same parties preferred to keep a cautious distance from the streets with the presidential elections approaching. In all three countries different kinds of demands coexisted, even though the protests and mobilisations started for specific reasons. In Brazil, the first protests of June 2013 were led by already existing social movements that historically had addressed public transportation issues. However, the violent reaction of the police, together with government and mainstream media attempts to delegitimise the protest, led to a public outcry that soon transformed into massive mobilisations made up mostly of 'common people', not usually politically active. A specific protest linked to transportation suddenly became a massive movement demonstrating against the high costs—economic and social—of hosting the football World Cup and the Olympic Games while the quality of public education and health care was falling. This was accompanied by other demonstrations, ranging from protests against police brutality and human 
rights violations and demands to democratise to media to requests for the recognition of the right to have different sexual preferences. In the Brazilian case the reaction of law enforcement bodies was excessive and very violent, leading to mass indignation. In the cases of Mexico and Guatemala, the police seem to have learned from the political backlash experienced in other countries of the region—or during previous internal episodes (Mexico, \#YoSoyız2)—following a repressive approach, and tactically stood aside.

In September 2014, Mexico was shaken by the forced disappearance of 43 students of the rural teachers' preparatory school of Ayotzinapa, in the state of Guerrero. Immediately following the event, hundreds of thousands of citizens began to gather and protest, demanding justice. The Ayoztinapa case uncovered thousands of other forced disappearances, an extended web of corruption and impunity linked to organised crime, and the government's deliberate manipulation of information. The demonstrations were convened by active citizens via social media with the hashtag \#YaMeCansé (enough), while the classic social movements - at least at the begining — and opposition parties had a very marginal role, if any. While social unrest had started because of the Ayotzinapa case, the mobilisations soon began focusing on other issues too, including widespread corruption, the unfair justice system, violence and insecurity. Many of those involved were once part of the \#YoSoyrz2 movement, which in 2012 had protested against the candidature of the current president Enrique Peña Nieto.

In April 2015 a corruption scandal involving the president and vice-president of Guatemala led to massive protests, calling for their resignation and prosecution. Following months of increasing public pressure, first the vice-president and then the president were forced to step down and face trial. This was something previously unheard of in one of the poorest, most unequal and most violent countries of the region, with a long record of repression of csos and of civil and human rights violations. The movement \#RenunciaYa (quit right now), which eventually led to such a historic outcome, was triggered mostly by urban middle class, non-politicised individuals. The demonstrations were convened via social media by active citizens, while the opposition parties had no role and traditional social movements joined only at a later stage. Even though the protests had erupted with regard to a specific scandal, it was the whole Guatemalan political system, accused of widespread corruption, which was placed under scrutiny. It is important to mention the role played by the International Commission against Impunity in Guatemala ${ }^{1}$ (Comisión

1 The CICIG has many attributes of an international prosecutor, but it operates under Guatemalan law, in the Guatemalan courts, and it follows Guatemalan criminal procedure. It 
Internacional Contra la Impunidad en Guatemala: CICIG) — backed up by the us and the international community. Not only did it uncover the corruption scandal, it also played a key role in calming protesters' fears. Guatemalan citizens were positively shocked by a 'functioning' judicial system and this was a key factor in their empowerment. It was this 'lack of fear' that the traditional political actors failed to anticipate.

\subsection{The Actors}

Because of the fluidity of the new movements, identifying clearly the actors within them represents an analytical challenge. Although-using network and media analysis - it is possible to identify the 'founding members' or 'stem cells' of the movements, with the increase of participation and the diversification of demands, mapping the actors becomes more challenging. Most of the players are not part of a formal movement - with registered members - and in most cases they can be only followed through Twitter or Facebook accounts. That organisational fluidity is at the same time the strength and weakness of these new forms of aggregation and activism.

If, on the one hand, the catalysing capacity of the founding members, thanks to ICTs and social media, leads to impactful protests, rapidly transforming small groups of individuals into mass mobilisations, on the other, those impressive demonstrations are apparently not backed by structured organisations with coordination capacities that can be maintained over time. We are witnessing the emergence of fluid movements, in which random individuals play a key role in terms of the impact of the mobilisations, while the convening groups are relatively small. These two groups of people, founding members, or stem cells, and circumstantial players, are not fixed categories. On the contrary, they mix and interchange roles rapidly, through social media, depending on the specific demands that arise over time.

In the Brazilian case, the mobilisations in 2013 were triggered by the Free Fare Movement (Movimento Pase Libre: MPL), an organised group that had been demanding free public transportation for years. However, the number of

carries out independent investigations into the activities of illegal security groups and clandestine security structures, which are defined as groups that: commit illegal acts that affect the Guatemalan people's enjoyment and exercise of their fundamental human rights, and have direct or indirect links to state agents or the ability to block judicial actions related to their illegal activities. The influence of these groups within the State is considered to be one of the cornerstones of impunity in the country and a major obstacle that impedes efforts to strengthen the rule of law. Source: CICIG website, http://www.cicig.org/index .php?page=about (accessed on 22 March 2017). 
organisations, associations, movements and, most importantly, ordinary citizens without any affiliation who joined the protests, grew so quickly that it was soon impossible to identify one clear leadership or key catalysing demands among the numerous demands raised. The result was multiple actors protesting for multiple reasons contemporarily, with no clear core mobilisation.

In Guatemala in 2015, the protests were convened by the urban middle class, using the social media hashtag \#RenunciaYa. Without any form of structured organisation, thousands of people, from across the whole political and class spectrums, took to the streets demanding justice and an end to corruption. Another characteristic of the movement was the widespread reaction and participation of Guatemalans abroad; this was not significant in terms of numbers perhaps, but had an important effect in terms of increasing national cohesion. One of the protesters' clear messages was that no political party, no matter its ideology, was welcome to join the demonstrations. Only in a later stage did pre-existing social movements and organised groups join the mobilisations.

Mexico is probably the case in which fluidity was more radical. This is illustrated by the case of the \#YoSoyız2 (2012) and \#YaMeCansé (2014-15) mobilisations. The \#YoSoyiz2 movement arose spontaneously in May 2012 as a message of support-channelled through social media — sent to the 131 students of the Universidad Iberoamericana who publicly opposed the then presidential candidate Enrique Peña Nieto in a forum held following a speech he gave on university premises. From social media, the movement moved to the streets and started coordinating and deliberating through more conventional dynamics, such as participatory assemblies-convening massive mobilisations that were enlarged by the participation of the urban middle class. The movement was openly opposed to political parties and collaborated only with a few existing indigenous movements and the radical Mexican Electrical Workers' Union (SME). Once Peña Nieto was elected at end of 2012, the movement seemed to disappear rapidly and to break down into small separated groups.

However, some analysts pointed out that it would be a mistake to consider the movement finished. The problem was the analytical lens that was being used: that of classical social movements. In fact, \#YoSoyız was kept alive via a network of active citizens connected through social media, mostly Twitter and Facebook, with a capacity for rapid mobilisation that could erupt around a given demand. This was proved in the following months by sudden demonstrations convened through this network: \#PosMeSalto, to protest against a rise in urban rail prices, and \#NoMasPoderAlPoder and \#ContraElSilencio, to protest against the government's attempt to increase control over internet usage. When the Ayotzinapa disappearances caused a widespread outcry in Mexico, the convening power of former \#YoSoyız2 members was confirmed again by 
the massive mobilisations that gathered around the hashtag \#YaMeCansé. A network analysis shows that many of the Twitter hubs that served as key convenors were shared by \#YoSoyrz2 and \#YaMeCansé.

In Brazil, Mexico and Guatemala the key players of the movements are young adults, joined in later stages by other generations. And among these young adults, university students play a key role, not always through formal student associations. Instead, the key players seem to be non-affiliated students or students affiliated to non-university movements such as non-governmental organisations (NGOS), or other csos. In Brazil for example the National Union of Students (Union Nacional de Estudiantes), the country's main and oldest students' union, had a marginal role in the 2013 mobilisations, while independent students took the lead, deliberating and coordinating through open participatory assemblies on a daily basis. In Mexico, the 131 students that triggered opposition to Peña Nieto's candidacy in 2012 were not affiliated to any organisation and, more surprisingly, all came from a private, elitist university with no history of political protests.

That the role played by traditionally active student associations was only secondary seems to have loosened the sociopolitical boundaries separating these youngsters from one another, allowing students and youths from different social classes to converge in the movements. In each of the three countries studied, students from private and public universities protested together. That was a striking departure from the past for such stratified societies where private and public always delimited the difference between the economic elite and the rest of the people. In Guatemala for example, in an unprecedented move, students from the Universidad de San Carlos de Guatemala, the Universidad Rafael Landívar, the Universidad del Valle de Guatemala and the Universidad Francisco Marroquín joined forces so they were able to organise more effective mobilisations. The same dynamic can be found among adult participants in the mobilisations. Here too, the fact that traditional social movements defined by clear political positioning only played a marginal role seems to have opened the doors to a freer participation of individuals sharing the same demands, but not always coming from the same sociocultural and political backgrounds.

It remains to be seen whether freer also means fairer. On the one hand, the loosening of political standpoints has allowed more participation from active citizens who are less and less associated with politics or classic movements. On the other hand, it can be argued that in a region where half of the population has never had access to Internet, the central role of ICTs and social media is exclusionary per se. This poses clear limits on who takes part in the mobilisations and with what roles, and explains the centrality of the urban middle class and youth. At the same time it may also raise doubts about the sociopolitical 
legitimacy of the new movements, which, although able to convene mass mobilisations, do not represent large strata of the population.

\subsection{Structures and Forms of Mobilisation}

Probably the most revolutionary aspect of the new movements resides in their structures and forms of mobilisation. Although most of the movements are linked to social demands that have existed in the region for decades, from the first years of the twenty-first century-with a sudden acceleration from 2011 on-they start to be characterised by features that break with the past, especially from a formal point of view. Therefore, while it can be argued that there is continuity of content, the social eruptions of recent years have been so impactful due to radically new forms of organisation, communication, coordination and aggregation. ICTs and social media do not seem to play a special role in the definition of content or new demands, but they do revolutionise the way in which these are transmitted and manifest themselves.

Horizontal communication allows participants to bypass classic organisers and conveners of mobilisations, such as 'old' movements, unions and opposition parties, facilitating the free participation of individuals in the protests. Organised protests, controlled and coordinated by party or union directives, lose their attraction; what becomes important is the role of the individual, connected - through the Internet - to others with a fast mobilisation capacity that does not need any prior form of organisation.

There is no unique centre of deliberation and coordination, while the culture of the virtual spread of the word and re-tweet predominates. The 'tweet' and the 'retweet' begin to replace coordination assemblies in the convening of protests and mobilisations. Anybody can start a chain of messages that become a collective call for impactful mobilisations, although these messages can also be ephemeral. As mentioned previously, this organisational fluidity is at once the great strength and the weakness of the new movements. Their rapidity of formation and dissolution disorients classic politics and law enforcement representatives, who do not know with whom, and where, to go in order to interact and control. At the same time, this also disorients more classic social movements, Csos, and NGOs that would be interested in establishing ties with the emerging actors of social activism in the region.

What stands out in these new forms of mobilisation is the importance of maintaining individual independence while participating in mass movements and protests. This creates a contradiction between the need to remain independent and the need to organise and coordinate a movement in order to have a political impact. Such a contradiction is evident in the case of Brazil, Guatemala and Mexico, where mobilisations have been wavy; that is, where there 
were impressive peaks in participant numbers, which deflated rapidly but, nevertheless, could 'inflate' again just as fast.

The question of whether a given political message or call for mobilisation is more or less relevant will be answered by whether it becomes 'viral' on social media. It is the Net, and those who are connected to it, that determines in a self organising fashion whether a call is important, and makes it effective or irrelevant. This 'instinctive' selection is based on whether social media users empathise with the political messages and calls for mobilisation that circulate on the Net. Online communication and mediation enable identification and awareness of other individuals sharing similar ideas and opinions and who may team up for a common cause (Cardoso, 2014). The mobilisations of recent years were the result of multiple voices and messages which took to the streets in the form of protests. However, before the protests erupted, those voices and messages were already present in everyday life and only in a second phase did they connect, gather and spread thanks to social media.

A study of the 2013 protests in Brazil shows that the mobilisations were characterised by the presence of small groups of people supporting the demands in question - which can be defined individually as the stem cells of the movements, and that only in a later stage did we witness 'the mimetic attitude' that led to a high number of participants in the protests. The mimetic attitude is a possibility; it is a personal choice that becomes real only when one realises that something is really happening (Cardoso, 2014). And it is at that stage - the realisation that something is happening - that social media's horizontal communication lines play a key role.

Guatemala's and Mexico's movements were characterised exactly by this dynamic. What changes is the size and number of the stem cells. While in Brazil they were numerous and dispersed, reflecting the existence of parallel demands, in Mexico they were fewer and more concentrated around the Peña Nieto candidature in 2012 and the Ayoztinapa case in 2014. In Guatemala they were even smaller than in Mexico, reflecting the country's social reality and population size. Thanks to social media, the act of being a stem cell and that of displaying the mimetic attitude are not mutually exclusive, and one can easily be part of a 'stem cell' today and a follower tomorrow, or the other way around.

The relationship between these emerging social actors or new movements and already existing organisations and groups varies from case to case. In Brazil, while the mobilisations were characterised by high fluidity and the retweet culture, the new actors also coexisted and interacted with some opposition parties and with more structured movements such as the M PL, the Comités Populares da Copa, the Centro de Mida Independente, the Homeless Workers Movement (Movimento dos Trabalhadores Sem Teto), the Red de Comunidades y 
Movimiento contra la Violencia, the Independent Popular Front (Frente Independente Popular) and the Movimento Periferia Activa, just to mention a few. The movements and organisations that participated in the 2013 protests were so many and varied that it was often possible to have several different demonstrations in the same urban space, with no coordination and articulation, with the obvious result of dispersed strength and no political impact.

The lack of formal coordination with other social actors was even more evident in the Mexican case, where the extreme fluidity of the \#YoSoyiz2 and the \#YaMeCansé movements made it almost impossible for these movements to join other organisations through formal channels. Links were established with the people of the indigenous community of Atenco and other indigenous organisations, with the SME, and with the parents of those who had disappeared. However, the movement changed so rapidly, disappearing and reappearing in the form of new groups or members and gathering around constantly evolving demands, that it is very difficult to keep track of its coordination through the lens of organisations that are structured more classically. One always doubts whether it is the movement that is coordinating or just somebody who was actively involved in the movement, but today is interacting as an individual.

In Guatemala, it could be argued that while in the initial state the mobilisations were convened by the urban middle class outside of any organised movement, more classic social movements, such as peasants' organisations and university student associations, have progressively increased their participation in the mobilisations. Furthermore, and this is a difference between the Guatemalan case and other cases, the protesters started to organise around more formal spaces of deliberation and coordination, such as the Plataforma Nacional para la Reforma del Estado, which presented a proposal to reform the electoral law, and the Asamblea Social y Popular, which gathers together 73 organisations involving-for example-students, indigenous peoples, peasants, women and scholars and which aimed to articulate a debate on the future of the country.

\section{3}

\section{Conclusions}

Although the above movements arose in different countries, with their own peculiarities, they all have more features in common than not. They grow in a specific regional context of increasing contradictions that arise from exclusionary economic development and incomplete social and human development, characterised by radical inequalities in democracies that still do not attend to the needs of large parts of society. 
These movements seem new, but they arise from underlying tensions in most societies in the region, tensions that have long represented the core of social conflict in Latin America: inequality, poverty and the exclusion they both imply. This exclusion is social (a lack of access to basic services, education, health, transport, etc.) and political (a lack of participation in decision-making processes, as well as self-referential political classes and opaque institutional processes, and a lack of political-institutional accountability).

All the movements had impacts on their countries and on the region in general. But it is still too early to develop a definitive evaluation of the effectiveness of such impacts, and - especially in the political field - a medium- and long-term perspective will be needed in order to assess their real reach. That said, some implications can already be identified in sociocultural terms and with regard to emerging players.

The Guatemalan case is somehow different from the other two in terms of political impact. It is worth emphasising that, in Guatemala, the movement erupted in the midst of an electoral campaign, sharpening disgust towards the political system. At the same time it gave greater leverage to the movement as candidates (especially those standing for Congress) feared missing out on reelection. However, while the movement led to the president and his deputies stepping down and a series of arrests, it was not able to gather around a political project and present its own candidate for the presidential elections held in September 2015. It is important to mention that this was not only because of a lack of the capacity to do so, but also due to lack of time. The protests occurred just a few weeks before the electoral process was officially convened. This led to a very interesting debate on the subject of the constitution. The majority of protesters were against reforming or 'disregarding' the constitution in order to stop the electoral process. A few others argued that respecting the constitution was not a requirement anymore, given that the social contract had been so utterly violated, and they proposed a transitional government.

Finally the elections were held, but in a political vacuum that opened the door to the triumph of the anti-politics candidate, Jimmy Morales. However, at the same time it can be argued that another outcome of the protests was the emergence of an accountability culture, in which we are seeing citizens being much more aware of what the new government is doing, and of the laws being passed in Congress.

In general, the most revolutionary aspect of the new social movements lies in their structures and forms of mobilisation, characterised by new dynamics that have radically broken with the past from a formal point of view. All the cases analysed here are evidence of the emergence, also in Latin America, of a liquid society — that is to say, of the need to take on a flexible and versatile 
identity; a process through which the individual must pass in order to join an increasingly global society, with no fixed identity, being malleable, changeable. Identity has to be invented, created; survival disguises must be moulded (Bauman, 2004). In the context of social movements and protests, this leads to the weakening of traditional forms of aggregation, and to the growth of the relevance and importance of circumstantial players, or to new forms of 'organisation' such as that carried out using networks.

This varies from case to case and if in Mexico and Guatemala these liquid organisations represent the foundation of new forms of mobilisation, in Brazil they move and join more structured and already existing social movements. In all cases, ICTs and social media play an important role, especially as a means of communication, aggregation, and coordination among those players, and less as a means of deliberation - except in Mexico. The more fluid social movements are, the more difficult it becomes, from the outside, to identify players with whom to interact.

The eruption and spread of protests is linked to the increasing diffusion of social networks and social media and coincides with the presence of new key players in the protests of recent years: the circumstantial metropolitan citizens who, through ICTs and new forms of communication, take part in mass protests on an ad hoc basis. However, these players are not involved either actively or in the long-term in the coordination and organisation of social movements. In the cases being analysed we must then distinguish between large demonstrations linked to 'traditional' social movements and social eruptions that are also expressed through large demonstrations but linked to the new forms of aggregation, organisation and coordination described in this chapter.

This distinction is important if we are to understand who the actual active players are in the renewed Latin American social activism landscape. In most cases we find social organisations and movements-large or small, organised or less so, depending on the country-in which young people have a central role, representing the stem cells of mobilisation and from whom the messages that lead to mass protests emerge. These movements do not have institutionalised coordinative mechanisms. This in many cases leads to a dispersion and dilution of the potential impact of mobilisations. This happens especially in countries-Brazil is the most obvious example-where there is a multitude of organisations, sometimes also very small, which move in parallel, leading to multiple micro-protests that have no long-term political impact.

Although we must differentiate between stem cells and circumstantial players, mass participation in protests seems to demonstrate that a new active citizenship is emerging-more attentive to and more keen to scrutinise politics, eager to participate in public issues affecting individual citizens' quality of life. 
In this sense, these new movements, especially mass mobilisations, are an expression of a mature democratic culture, where citizens are outraged and fight for rights that are no longer questionable.

\section{References}

Bauman, Z. (2004) Modernidad Liquida (México: Fondo de Cultura Económica).

Branco, M. (2014) 'Brasil 2013. La Calle y La Presidenta', Vanguardia Dossier, 50, pp. 83-93.

Calderón, F. and A. Szmukler (2014) 'Los Jóvenes en Chile, México y Brasil. Disculpe las molestias estamos cambiando el país', Vanguardia Dossier, 50, pp. 89-93.

Cardoso, G. (2014) 'Movilización Social y Medios Sociales', Vanguardia Dossier, 50, pp. $17-27$.

Castells, M. (2014) 'El poder de las redes', Vanguardia Dossier, 50, pp. 8-13

Latinobarómetro (2015) Informe sobre la confianza en América Latina 1995-2015 (Santiago de Chile: Corporación Latinobarómetro), http://www.latinobarometro. org/latNewsShowMore.jsp?evYEAR=2015\&evMONTH=-1 (accessed on 19 January 2017).

Latinobarómetro (2013) Informe 2013 (Santiago de Chile: Corporación Latinobarómetro), http://www.latinobarometro.org/documentos/LATBD_INFORME_LB_2013.pdf (accessed on 19 January 2017).

Pellizzetti, P. (2014) 'No todo el que dice "redes, redes" entrará en el reino de los "networks", Vanguardia Dossier, 5o, pp. 64-68.

PNUD-PAPEP (Proyecto de Análisis Político y Escenarios Prospectivos) (2012) La Protesta Social en América Latina (Buenos Aires: Siglo vientiuno editores).

Revilla Blanco, M. (1996) 'El concepto de movimiento social: Acción, identidad y sentido', Última Década, 5 (Valparaíso, Chile: Centro de Estudios Sociales), pp. 1-18, http://www.redalyc.org/articulo.oa?id=19500501 (accessed on 19 January 2017). 